\section{AKSESIBILITAS PEMBIAYAAN KESEHATAN DALAM PROGRAM JAMINAN KESEHATAN NASIONAL ${ }^{1}$}

Oleh: Deysi Liem Fat Salim²

Nontje Rimbing ${ }^{3}$

Theodorus H. W. Lumunon ${ }^{4}$

\section{ABSTRAK}

Tujuan edilakukannya penelitian adalah untuk mengetahui bagaimana Pengaturan Hukum mengenai Aksesibilitas Ekonomi dalam Program Jaminan Kesehatan Nasional dan bagaimana Implementasi Tanggung Jawab Negara terhadap Pembiayaan Kesehatan dalam
\end{abstract} Program Jaminan Kesehatan Nasional sebagai Pemenuhan Hak Atas Kesehatan, di mana dengan metode penelitian hukum normatif disimpulkan bahwa: 1. Hak atas kesehatan sebagai hak mendasar bagi setiap individu secara tegas telah dinyatakan dalam Pasal $28 \mathrm{H}$ dan Pasal 34 Undang-Undang Dasar 1945 dan Undang-Undang Nomor 11 Tahun 2005 tentang Pengesahan International Covenant on Economic, Social and Cultural Rights bahwa setiap orang berhak atas pelayanan kesehatan dan negara bertanggung jawab atas penyediaan fasilitias pelayanan kesehatan. Berdasarkan hal tersebut, upaya pemenuhan hak atas kesehatan bagi seluruh masyarakat, maka dibentuklah Undang-Undang Nomor 36 Tahun 2009 tentang Kesehatan, Undang-Undang Nomor 40 Tahun 2004 tentang Sistem Jaminan Sosial Nasional, Undang-Undang Nomor 24 Tahun 2011 tentang Badan Penyelenggara Jaminan Sosial dan Peraturan Presiden Nomor 82 Tahun 2018 tentang Jaminan Kesehatan. 2. Jaminan Kesehatan Nasional menerapkan sistem pelayanan kesehatan berjenjang, yang terdiri atas Fasilitas Kesehatan Tingkat Pertama (FKTP) dan Fasilitas Kesehatan Tingkat Rujukan Lanjutan (FKRTL). Dalam hal pembiayaan kesehatan, sumber pembiayaan berasal dari pemerintah yang diatur dalam Pasal 171 UU Nomor 36 Tahun 2009 tentang Kesehatan, dialokasikan sebesar 5\% dari APBN di luar gaji dan sebesar $10 \%$ dari APBD di luar gaji.

Kata kunci: pembiayaan kesehatan; jaminan kesehatan nasional;

\footnotetext{
${ }^{1}$ Artikel Skripsi

2 Mahasiswa pada Fakultas Hukum Unsrat, NIM: 16071101054

${ }^{3}$ Fakultas Hukum Unsrat, Magister IImu Hukum

${ }^{4}$ Fakultas Hukum Unsrat, Doktor IImu Hukum
}

\section{PENDAHULUAN}

\section{A. Latar Belakang}

Tujuan dari Undang-Undang Nomor 40 Tahun 2004 tentang Sistem Jaminan Sosial Nasional, yaitu untuk menjamin adanya aksesibilitas terhadap pelayanan kesehatan. Di dalamnya terdapat ketentuan mengenai jaminan kesehatan yang diselenggarakan berdasarkan prinsip asuransi sosial dan prinsip ekuitas. Sebagai amanat dari Undang-Undang Sistem Jaminan Sosial Nasional, maka terhitung mulai 1 Januari 2014 dibentuklah Badan Penyelenggara Jaminan Sosial (BPJS) Kesehatan yang merupakan perubahan bentuk dari PT Asuransi Kesehatan (ASKES) yang ditugaskan sebagai penyelenggara Jaminan Sosial di bidang kesehatan. Tugas dari BPJS Kesehatan itu sendiri, yakni bagaimana secara bertahap dapat memberikan jaminan kepada pengelola program kesehatan masyarakat, Badan Penyelenggara Jaminan Sosial Kesehatan. Ini dikuatkan berdasarkan Undang-Undang Nomor 24 Tahun 2011 tentang Badan Penyelenggara Jaminan Sosial ${ }^{5}$. Peserta BPJS Kesehatan secara umum dikelompokkan menjadi dua, yaitu Penerima Bantuan luran (PBI) dan bukan PBI. Peserta $\mathrm{PBI}$ merupakan warga yang iurannya dibayarkan menggunakan dana APBN atau APBD.

\section{B. Rumusan Masalah}

1. Bagaimana Pengaturan Hukum mengenai Aksesibilitas Ekonomi dalam Program Jaminan Kesehatan Nasional?

2. Bagaimana Implementasi Tanggung Jawab Negara terhadap Pembiayaan Kesehatan dalam Program Jaminan Kesehatan Nasional sebagai Pemenuhan Hak Atas Kesehatan?

\section{Metode Penelitian}

Metode yang digunakan dalam penelitian ini adalah metode yuridis normatif atau penelitian hukum doktrinal.

\section{PEMBAHASAN}

\footnotetext{
${ }^{5}$ Insan Firdaus, Pemenuhan Hak Atas Kesehatan melalui Badan Penyelenggara Jaminan Sosial Kesehatan di Indonesia, Jurnal Hak Asasi Manusia Volume 5 No. 2, Desember 2014.
} 


\section{A. Pengaturan Hukum Mengenai Aksesibilitas Ekonomi dalam Program Jaminan Kesehatan Nasional}

Dalam beberapa Konvensi Internasional dan dokumen hukum internasional, ketentuan mengenai hak atas kesehatan ditetapkan sebagai salah satu hak dasar (hak fundamental) yang dimiliki oleh setiap individu, dimana hak ini harus dihormati dan dipenuhi oleh negara tanpa membedakan suku, agama, latar belakang politik, ekonomi maupun kondisi sosial. Berdasarkan hal tersebut hak atas kesehatan diakui sebagai "hak dasar" oleh masyarakat internasional sejak diadopsi dari Konstitusi WHO pada tahun 1946. Kemudian, dipertegas dalam Komentar Umum dari Komite Hak-Hak Ekonomi, Sosial, dan Budaya terhadap hak atas kesehatan, yaitu "Health is a fundamental human right indispensable for the exercise of other human rights" ${ }^{\prime \prime}$. Berdasarkan komentar umum tersebut, kesehatan ditempatkan sebagai hak asasi manusia yang fundamental dan tak ternilai demi terlaksananya hak asasi manusia yang lainnya.

Kesehatan adalah keadaan sejahtera dari badan, jiwa, dan sosial yang memungkinkan setiap orang hidup produktif secara sosial dan ekonomis ${ }^{7}$. Pemeliharaan kesehatan adalah upaya penangggulan dan pencegahan gangguan kesehatan yang memerlukan pemeriksaan, pengobatan dan/atau perawatan termasuk kehamilan dan persalinan. Jaminan kesehatan merupakan bagian dari upaya untuk mencapai Universal Health Coverage yang selanjutnya disingkat UHC, di mana menurut WHO, UHC merupakan sistem kesehatan di mana setiap warga di dalam populasi memiliki akses yang adil terhadap pelayanan kesehatan promotif, preventif, kuratif, dan rehabilitatif, yang bermutu dan dibutuhkan dengan biaya yang terjangkau. Ruang lingkup dari UHC itu sendiri mengandung 2 (dua) elemen inti, yakni: 1. Akses pelayanan kesehatan yang adil dan bermutu bagi setiap warga; dan 2. Perlindungan risiko finansial ketika warga menggunakan pelayanan kesehatan.

\footnotetext{
${ }^{6}$ CESCR General Comment No.14: The Right To The Highest Attainable Standard Of Health (Art 12), (Committe on Social and Cultural Rights, 2000), No. 1, hlm. 1.

${ }^{7}$ Siti Nafsiah, "Prof. Hembing pemenang the Star of Asia Award: pertama di Asia ketiga di dunia". Gema Insani, 2000.
}

Dalam Pembukaan Undang-Undang Dasar Negara Republik Indonesia Tahun 1945 telah diamanatkan kepada Negara, bahwa tujuan negara adalah untuk meningkatkan kesejahteraan rakyat. Dalam Perubahan Keempat Undang-Undang Dasar Negara Republik Indonesia Tahun 1945, tujuan tersebut semakin dipertegas, yaitu dengan mengembangkan Sistem Jaminan Sosial bagi Kesejahteraan Seluruh Rakyat. Tujuan tersebut termuat dalam Pasal 28H UUD NRI Tahun 1945: (1) setiap orang berhak hidup sejahtera lahir dan batin, bertempat tinggal, dan mendapatkan lingkungan hidup yang baik dan sehat serta berhak memperoleh pelayanan kesehatan; (2) setiap orang berhak mendapat kemudahan dan perlakuan khusus untuk memperoleh kesempatan dan manfaat yang sama guna mencapai persamaan dan keadilan; (3) setiap orang berhak atas jaminan sosial yang memungkinkan pengembangan dirinya secara utuh sebagai manusia yang bermartabat. Selain dalam Pasal $28 \mathrm{H}$, dalam Undang-Undang Nomor 36 Tahun 2009 tentang Kesehatan menegaskan bahwa setiap orang mempunyai hak yang sama dalam memperoleh akses atas sumber daya di bidang kesehatan dan memperoleh pelayanan kesehatan yang aman, bermutu, dan terjangkau.

Kesadaran tentang pentingnya jaminan perlindungan sosial terus berkembang sesuai dengan amanat pada perubahan Pasal 34 ayat (2) UUD 1945, yang mengatakan bahwa negara mengembangkan Sistem Jaminan Sosial bagi seluruh rakyat Indonesia, kemudian dengan terbitnya Undang-Undang Nomor 40 Tahun 2004 tentang Sistem Jaminan Sosial Nasional yang selanjutnya disingkat dengan UU SJSN menjadi salah satu bukti yang kuat bahwa pemerintah dan pihak-pihak yang terkait memiliki komitmen yang besar untuk mewujudkan kesejahteraan sosial bagi seluruh rakyatnya dan salah satu bentuk perlindungan sosial. Selain itu, pada hakekatnya bertujuan untuk menjamin seluruh rakyat agar dapat memenuhi kebutuhan dasar hidup yang layak.

Dengan ditetapkannya UU SJSN diharapkan dapat memberikan perlindungan sosial bagi seluruh rakyat Indonesia secara menyeluruh dan terpadu, maka dari itu pemerintah bertanggung jawab atas pelaksanan jaminan kesehatan masyarakat melalui program 
Jaminan Kesehatan Nasional yang selanjutnya dengan JKN. Upaya ke arah itu sesungguhnya telah dilakukan oleh pemerintah dengan menyelenggarakan beberapa bentuk jaminan sosial di bidang kesehatan, diantaranya adalah melalui PT Askes (Persero) yang melayani antara lain pegawai negeri sipil (PNS), penerima pensiun, veteran, dan pegawai swasta. Untuk masyarakat miskin dan tidak mampu, pemerintah memberikan jaminan melalui skema Jaminan Kesehatan Masyarakat (Jamkesmas) dan Jaminan Kesehatan Daerah (Jamkesda). Namun demikian, skema-skema tersebut masih terfragmentasi, terbagi-bagi sehingga biaya kesehatan dan mutu pelayanan menjadi sulit terkendali ${ }^{8}$.

Untuk mengatasi hal tersebut, pada tahun 2004 dikeluarkanlah Undang-Undang Nomor 40 Tahun 2004 tentang Sistem Jaminan Sosial Nasional. Undang-Undang ini memberi amanat bahwa program jaminan sosial wajib bagi seluruh penduduk termasuk program Jaminan Kesehatan melalui suatu badan penyelenggara jaminan sosial. Untuk mewujudkan tujuan sistem jaminan sosial nasional perlu dibentuk badan penyelenggara yang berbentuk badan hukum publik berdasarkan prinsip kegotongroyongan, nirlaba, keterbukaan, kehati-hatian, akuntabilitas, portabilitas, kepesertaan, bersifat wajib, dana amanat, dan hasil pengelolaan Dana Jaminan Sosial dipergunakan seluruhnya untuk pengembangan program dan sebesar-besarnya untuk kepentingan Peserta.

Kemudian, untuk pembentukan UndangUndang tentang Badan Penyelenggara Jaminan Sosial, maka diterbitkanlah dalam UndangUndang Nomor 24 Tahun 2011. Pembentukan ini merupakan pelaksanaan UU Sistem Jaminan Sosial Nasional, setelah Putusan Mahkamah Konstitusi terhadap perkara Nomor 007/PUUIII/2005, guna memberikan kepastian hukum bagi pembentukan BPJS untuk melaksanakan program Jaminan Sosial di seluruh Indonesia ${ }^{9}$. Undang-Undang ini merupakan pelaksanaan dari Pasal 5 ayat (1) dan Pasal 52 Undang-

\footnotetext{
${ }^{8}$ Lihat Bab 1 Peraturan Menteri Kesehatan Nomor 28 Tahun 2014 tentang Pedoman Pelaksanaan Program Jaminan Kesehatan Nasional.

${ }^{9}$ Lihat Penjelasan atas Undang-Undang Republik Indonesia Nomor 24 Tahun 2011 tentang Badan Penyelenggara Jaminan Sosial.
}

Undang Nomor 40 Tahun 2004 tentang Sistem Jaminan Sosial Nasional yang mengamanatkan pembentukan Badan Penyelenggara Jaminan Sosial dan transformasi kelembagaan PT Askes (Persero), PT Jamsostek (Persero), PT TASPEN (Persero), dan PT ASABRI (Persero) menjadi Badan Penyelenggara Jaminan Sosial yang selanjutnya disingkat dengan BPJS. Transformasi tersebut diikuti adanya pengalihan peserta, program, aset dan liabilitas, pegawai, serta hak dan kewajiban. Dengan Undang-Undang ini dibentuk, maka kelembagaan BPJS yang awalnya terdiri atas 4 (empat) lembaga sekarang hanya terdiri atas 2 (dua) bagian saja, yaitu BPJS Kesehatan dan BPJS Ketenagakerjaan. BPJS Kesehatan menyelenggarakan program jaminan kesehatan dan BPJS Ketenagakerjaan menyelenggarakan program jaminan kecelakaan kerja, jaminan hari tua, jaminan pensiun, dan jaminan kematian. Dengan terbentuknya kedua BPJS tersebut jangkauan kepesertaan program jaminan sosial akan diperluas secara bertahap. BPJS Kesehatan itu sendiri mulai beroperasi menyelenggarakan Program Jaminan Kesehatan pada tanggal 1 Januari 2014 dan merupakan tranformasi kelembagaan dari PT Askes (Persero).

Dalam hal ini negara telah menetapkan langkah-langkah untuk merealisasikan pemenuhan hak atas kesehatan melalui Jaminan Kesehatan Nasional yang merupakan bagian dari Sistem Jaminan Sosial Nasional. Salah satu langkah yang telah dibuat oleh pemerintah selain mengeluarkan UU Nomor 36 Tahun 2009, UU Nomor 40 Tahun 2004 tentang Sistem Jaminan Sosial Nasional dan UU Nomor 24 Tahun 2011 tentang Badan Penyelenggara Jaminan Sosial, yaitu dengan mengeluarkan Peraturan Presiden Nomor 12 Tahun 2013 tentang Jaminan Kesehatan. Peraturan Presiden Nomor 12 Tahun 2013 telah mengalami beberapa kali perubahan, antara lain sebagaimana diubah dengan Peraturan Presiden Nomor 111 Tahun 2013, Peraturan Presiden Nomor 19 Tahun 2016 yang menjadi Perubahan Kedua, dan terakhir, yaitu Peraturan Presiden Nomor 28 Tahun 2016. Namun, seiring dengan berjalannya waktu dan pemerintah melihat Perpres ini perlu untuk disempurnakan demi meningkatkan kualitas dan kesinambungan dalam program Jaminan 
Kesehatan. Berdasarkan pertimbangan yang telah dilakukan oleh pemerintah, maka ditetapkanlah Peraturan Presiden Nomor 82 Tahun 2018 tentang Jaminan Kesehatan. Setahun kemudian, setelah Perpres Nomor 82 Tahun 2018 ditetapkan, pemerintah melakukan perubahan atas beberapa ketentuan dalam Perpres tersebut dengan tujuan untuk meningkatkan kualitas dan kesinambungan program jaminan kesehatan. Perubahan Perpres Nomor 82 Tahun 2018 termuat dalam Peraturan Presiden Nomor 75 Tahun 2019 tentang Perubahan Atas Peraturan Presiden Nomor 82 Tahun 2018 tentang Jaminan Kesehatan, ketentuan yang diubah dalam Perpres ini ialah mengenai kenaikan luran BPJS yang tercantum dalam Pasal 29, Pasal 30 ayat (2), Pasal 32 ayat (1) dan ayat (2), Pasal 33 ayat (1), di antara Pasal 34 disisipkan 1 (satu) pasal, yakni Pasal 33A, Pasal 34, dan di antara Pasal 103 dan Pasal 104 disisipkan 1 (satu) pasal, yakni Pasal 103A. Beberapa bulan setelah Perpres tersebut dikeluarkan, Mahkamah Agung membatalkan pasal yang mengatur tentang kenaikan iuran BPJS. Kemudian, setelah Mahkamah Agung membatalkan hal tersebut Presiden mengeluarkan Peraturan Presiden Nomor 64 Tahun 2020 tentang Perubahan Kedua Atas Peraturan Presiden Nomor 82 Tahun 2018 tentang Jaminan Kesehatan. Pasalpasal yang berubah masih mengenai tentang Iuran dan ketentuan-ketentuan yang berubah, yakni Pasal 28 dan Pasal 31 yang dihapus, Pasal 29, Pasal 30, Ketentuan ayat (1), ayat (2), dan ayat (4) Pasal 32, Pasal 34 yang diubah isinya. Diantara Pasal 34 dan Pasal 35 disisipkan 1 (satu) Pasal, yaitu Pasal 34A. Diantara Pasal 35 dan Pasal 36 disisipkan 1 (satu) pasal, yakni Pasal 35A. Diantara Pasal 36 dan Pasal 37 disisipkan 1 (satu) pasal, yakni Pasal 36A. Ketentuan ayat (1) Pasal 37 dan Ketentuan Pasal 38 diubah. Ketentuan ayat (5), ayat (6), ayat (7), ayat (8), dan ayat (9) Pasal 42 diubah dan diantara ayat (3) dan ayat (4) Pasal 42 disisipkan 2 (dua) ayat, yakni ayat (3a) dan ayat (3b) serta diantara ayat (6) dan ayat (7) Pasal 42 disisipkan 1 (satu) ayat, yakni ayat (6a). Diantara Pasal 54 dan Pasal 55 disisipkan 2 (dua) pasal, yakni Pasal 54A dan Pasal 54B.

Selain, Peraturan Presiden yang mengatur tentang Jaminan Kesehatan, adapun beberapa ketentuan yang mengatur juga tentang Jaminan
Kesehatan di Indonesia, yaitu Peraturan Menteri Kesehatan Nomor 71 Tahun 2013 tentang Pelayanan Kesehatan Pada Jaminan Kesehatan Nasional sebagaimana telah diubah dengan Peraturan Menteri Kesehatan Nomor 99 Tahun 2015 dan terakhir diubah dengan Peraturan Menteri Kesehatan Nomor 23 Tahun 2017, Peraturan Menteri Kesehatan Nomor 28 Tahun 2014 tentang Pedoman Pelaksanaan Program Jaminan Kesehatan Nasional. Peraturan Menteri Kesehatan Nomor 27 Tahun 2014 tentang Petunjuk Teknis Sistem Indonesian Case Base Groups (INA-BG's) sebagaimana telah diubah untuk menyesuaikan dengan perkembangan dan kebutuhan pelayanan kesehatan, sehingga perlu disempurnakan dengan Peraturan Menteri Kesehatan Nomor 76 Tahun 2016 tentang Pedoman Indonesian Case Base Groups (INACBG) dalam Pelaksanaan Jaminan Kesehatan. Peraturan Menteri Kesehatan Nomor 59 Tahun 2014 tentang Standar Tarif Pelayanan Kesehatan dalam Penyelenggaraan Program Jaminan Kesehatan sebagaimana telah diubah dengan Peraturan Menteri Kesehatan Nomor 12 Tahun 2016, namun untuk menyesuaikan dengan perkembangan dan kebutuhan pelayanan kesehatan di fasilitas kesehatan, sehingga peraturan ini disempurnakan dengan Peraturan Menteri Kesehatan Nomor 52 Tahun 2016. Kemudian, Peraturan Pemerintah Nomor 101 Tahun 2012 tentang Penerima Bantuan Iuran Jaminan Kesehatan dan untuk aturan yang mengatur mengenai sistem rujukan diatur dalam Peraturan Menteri Kesehatan Nomor 1 Tahun 2012 tentang Sistem Rujukan Pelayanan Kesehatan Perorangan.

\section{B. Implementasi Tanggung Jawab Negara terhadap Pembiayaan Kesehatan dalam Program Jaminan Kesehatan Nasional sebagai Pemenuhan Hak Atas Kesehatan}

Indonesia adalah negara hukum yang dinamis (Welfare state, negara kesejahteraan) yang memiliki asas-asas hukum diantaranya adalah asas penyelenggaraan kepentingan umum. Berdasarkan asas ini, segenap aparat pemerintah dituntut untuk melakukan kegiatan-kegiatan yang menuju pada penyelenggaraan kepentingan umum dan dapat memberikan perlindungan hukum bagi 
masyarakat ${ }^{10}$. Sebagaimana, disebutkan dalam bagian menimbang huruf a Undang-Undang BPJS, yaitu "bahwa sistem jaminan sosial nasional merupakan program negara yang bertujuan memberikan kepastian perlindungan dan kesejahteraan sosial bagi seluruh rakyat". Konsekuensi dari konsep Negara Kesejahteraan adalah bahwa negara bertanggung jawab untuk mewujudkan kesejahteraan rakyatnya, dengan turut serta dalam urusan warganya mulai manusia lahir sampai manusia mati (from the cradle to the grave), sehingga diibaratkan tak ada satu sisi kehidupan pun dari kehidupan warganya yang tidak dicampurtangani oleh pemerintah. Salah satu bentuk campur tangan pemerintah dalam kehidupan masyarakatnya adalah dalam bidang kesehatan untuk mewujudkan derajat kesehatan yang setinggitingginya dan ini merupakan tanggung jawab dari pemerintah ${ }^{11}$.

Rencana Strategis (Renstra) Kementerian Kesehatan merupakan dokumen perencanaan yang bersifat indikatif memuat programprogram pembangunan kesehatan yang akan dilaksanakan oleh Kementerian Kesehatan dan menjadi acuan dalam penyusunan perencanaan tahunan. Pembangunan kesehatan pada periode 2015-2019 adalah Program Indonesia Sehat dengan sasaran meningkatkan derajat kesehatan dan status gizi masyarakat melalui upaya kesehatan dan pemberdayaan masyarakat yang didukung dengan perlindungan finansial dan pemerataan pelayanan kesehatan. Sasaran pokok RPJMN (Rencana Pembangunan Jangka Menengah Nasional) 2015-2019 adalah $^{12}$ :

1) Meningkatnya status kesehatan dan gizi ibu dan anak;

2) Meningkatnya pengendalian penyakit;

3) Meningkatnya akses dan mutu pelayanan kesehatan dasar dan rujukan terutama di

\footnotetext{
${ }^{10}$ C.S.T. Kansil, Pengantar IImu Hukum dan Tata Hukum di Indonesia, Jilid I, Balai Pustaka, Jakarta, 2002. hIm. 22.

${ }^{11}$ Endang Wahyati Yustina, Hak Atas Kesehatan dalam Program Jaminan Kesehatan Nasional dan Corporate Social Responsibility (CSR), Kisi Hukum Jurnal Ilmiah Hukum.

${ }^{12}$ Yeni Tri Herwanto, "Rencana Strategis Kementerian Kesehatan Tahun 2015-2019", https://www.google.com/amp/s/promkes.net/2019/03/3 0/rencana-strategis-kementerian-kesehatan-tahun-20152019/amp/?espv=1 diakses pada 28 Agustus 2020 Pukul 01.15 Wita.
}

daerah terpencil, tertinggal dan perbatasan;

4) Meningkatnya cakupan pelayanan kesehatan universal melalui Kartu Indonesia Sehat dan kualitas pengelolaan SISN Kesehatan;

5) Terpenuhinya kebutuhan tenaga kesehatan, obat dan vaksin; serta

6) Meningkatnya responsivitas sistem kesehatan.

Jaminan Kesehatan berlaku bagi setiap individu (warga negara) semestinya menjadi kewajiban dari negara untuk memenuhinya tanpa membedakan warga negara yang satu dengan yang lainnya. Dalam melaksanakan program jaminan kesehatan nasional konsep yang dipergunakan adalah asuransi kesehatan sosial yang mencakup seluruh masyarakat, yang dalam hal ini seluruh rakyat Indonesia bersifat wajib menjadi peserta dalam program $\mathrm{ini}^{13}$. Setiap peserta dalam program Jaminan Kesehatan Nasional ditetapkan iuran bagi peserta, dalam hal ini negara membagi 2 (dua) bentuk kepesertaan, yaitu Penerima Bantuan Iuran (PBI) dan Bukan Penerima Bantuan luran (Bukan PBI). Penerima Bantuan luran, meliputi orang yang tergolong fakir miskin dan orang tidak mampu yang iurannya dibayarkan oleh negara, sedangkan Bukan Penerima Bantuan Iuran (Bukan PBI) adalah Peserta yang tidak tergolong fakir miskin dan orang tidak mampu yang iurannya tidak dibayarkan oleh negara. Berdasarkan hal tersebut dapat dilihat, bahwa negara memberikan perlakuan yang berbeda terhadap warga negaranya dalam pemberlakuan jaminan kesehatan, dimana seharusnya hal itu menjadi kewajiban dari negara untuk memenuhinya tanpa membedakan warga negara yang satu dengan yang lainnya.

Sesuai dengan telah disahkannya UndangUndang Nomor 24 Tahun 2011 tentang Badan Penyelenggara Jaminan Sosial dan untuk BPJS Kesehatan mulai resmi beroperasi pada 1 Januari 2014, maka dari itu BPJS telah menyelenggarakan jaminan kesehatan nasional bagi seluruh rakyat Indonesia yang masyarakat mampu maupun tidak mampu. Tapi, dalam menyelenggarakan program tersebut, BPJS

\footnotetext{
13 Rico Mardiansyah, Dinamika Politik Hukum Dalam Pemenuhan Hak Atas Kesehatan di Indonesia, VeJ Volume 4, Nomor 1, 2018, hlm 232.
} 
membutuhkan upaya bersama dengan pemerintah untuk meningkatkan kualitas dan keterjangkauan masyarakat terhadap pelayanan kesehatan yang bermutu dan pemerataan pembiayaan kesehatan.

Rendahnya kualitas pelayanan publik merupakan salah satu sorotan yang diarahkan kepada birokrasi pemerintah dalam memberikan pelayanan kepada masyarakat. Perbaikan pelayanan publik di era/reformasi merupakan harapan seluruh masyarakat, namun perjalanannya ternyata tidak mengalami perubahan yang signifikan. Berbagai tanggapan masyarakat justru cenderung menunjukkan bahwa berbagai jenis pelayanan publik mengalami kemunduran yang sebagian ditandai dengan banyaknya penyimpangan dalam layanan publik yang lamban dalam memberikan pelayanan juga merupakan aspek layanan publik yang banyak disoroti. Dalam bidang layanan publik, upaya-upaya telah dilakukan dengan menetapkan standar pelayanan publik dalam mewujudkan standard pelayanan publik yang cepat, murah, dan transparan. Hal tersebut terkait dengan pelaksanaan sistem dan prosedur pelayanan yang kurang efektif, berbelit-belit, lamban, tidak merespon kepentingan pelanggan, dan lain-lain adalah sederetan atribut negatif yang dilimpahkan kepada birokrasi ${ }^{14}$.

Implementasi program JKN belum maksimal dan menyeluruh kepada masyarakat karena kurangnya sosialisasi kepada masyarakat mengenai pentingnya program yang diadakan oleh pemerintah, sehingga masyarakat sudah beranggapan lebih dulu bahwa pelayanan yang akan diberikan akan lambat dan berbelit-belit, sehingga masyarakat lebih memilih untuk merogoh kocek sendiri untuk membiayai perawatan di fasilitas kesehatan bahkan ada yang lebih memilih tidak ke fasilitas kesehatan sama sekali karena faktor dari birokrasi pemerintah itu sendiri yang perbaikannya belum mengalami peningkatan yang signifikan.

Masyarakat yang berada di daerah terpencil tidak memiliki banyak pilihan dalam hal untuk berobat, sementara masyarakat yang berada di daerah perkotaan relatif fasilitas kesehatan sudah banyak, sehingga penggunaan fasilitas

\footnotetext{
${ }^{14}$ Ladzi Safroni. 2012. Manajemen dan Reformasi Pelayanan Publik dalam Konteks Birokrasi Indonesia. Surabaya: Aditya Media Publishing, hal. 14.
}

akan lebih sering dan benefit package yang tidak terbatas. Penyediaan pelayanan kesehatan tergantung pada infrastruktur di masyarakat, tanpa ada perbaikan infrastruktur pemerataan pelayanan kesehatan menjadi sulit dan jaminan kesehatan bagi masyarakat merupakan suatu hal yang tidak adil, tanpa peningkatan supply di daerah tertentu, dana BPJS akan tersedot ke daerah-daerah perkotaan.

Pembiayaan kesehatan secara menyeluruh berhubungan dengan strategi kebijakan pembiayaan dan BPJS merupakan salah satu sumber dana. Ketersediaan fasilitas kesehatan yang dilengkapi sumber daya manusia dan peralatan yang standar sangat mempengaruhi pendapatan anggaran yang bersumber dari BPJS. Pembiayaan investasi dan tenaga tertentu untuk meningkatkan kemampuan tindakan medik belum tercakup oleh BPJS dan hal ini menjadi beban Pemerintah Kabupaten/Kota dan Provinsi ${ }^{15}$.

Sesuai dengan Undang-Undang Nomor 32 Tahun 2004 tentang Pemerintah Daerah, mengatakan bahwa bidang kesehatan merupakan urusan Pemerintah Pusat, Pemerintah Provinsi dan Kabupaten/Kota ${ }^{16}$. Kemudian, dalam UU Nomor 32 Tahun 2004, dijelaskan bahwa Pemerintah Daerah (Provinsi/Kabupaten Kota) mempunyai kewajiban meningkatkan kualitas kehidupan masyarakat, mewujudkan keadilan dan pemerataan, menyediakan fasilitas pelayanan kesehatan, menyediakan fasilitas sosial dan fasilitas umum yang layak, mengembangkan sistem jaminan sosial ${ }^{17}$. Kemudian dalam Peraturan Pemerintah Nomor 38 Tahun 2007 tentang Pembagian Urusan Pemerintahan antara Pemerintah, Pemerintahan Daerah Provinsi, dan Pemerintahan Daerah Kabupaten/Kota, diamanatkan bahwa bidang kesehatan merupakan urusan pemerintahan yang dibagi bersama antar tingkatan dan/atau susunan pemerintahan yang disebut juga dengan urusan pemerintahan yang bersifat

\footnotetext{
15 Yandrizal, Hendarini, Desri Suryani, "Analisis Ketersediaan Fasilitas dan Pembiayaan Kesehatan pada Pelaksanaan Jaminan Kesehatan Nasional di Provinsi Bengkulu", Jurnal Kebijakan Kesehatan Indonesia, Volume 03, Nomor 04, Desember 2014, hlm. 221.

${ }^{16}$ Lihat Pasal 11 Undang-Undang Nomor 32 Tahun 2004 tentang Pemerintahan Daerah.

${ }^{17}$ Ibid Pasal 22.
} 
konkuren, yang diselenggarakan bersama oleh Pemerintah, Pemerintahan Daerah Provinsi dan Pemerintahan Daerah Kabupaten $/ \operatorname{Kota}^{18}$. Berdasarkan UU Pemerintah Daerah untuk menyelenggarakan jaminan kesehatan bagi masyarakatnya, dibiayai melalui Anggaran Pendapatan dan Belanja Daerah (APBD) maupun kontribusi dari masyarakat. Selain itu, dalam Pasal 171 UU Nomor 36 Tahun 2009 tentang Kesehatan telah mengatur besaran anggaran kesehatan pemerintah dialokasikan minimal $5 \%$ dari anggaran pendapatan dan belanja negara di luar gaji dan bagi pemerintah daerah provinsi, kabupaten/kota dialokasikan minimal $10 \%$ dari anggaran pendapatan belanja daerah di luar gaji.

Pembiayaan kesehatan secara menyeluruh berhubungan erat dengan strategi kebijakan pembiayaan diluar skema BPJS. Seperti diketahui saat ini anggaran kesehatan pemerintah pusat terbagi atas 4 (empat) kelompok besar, yaitu:

1. Anggaran yang berada di BPJS;

2. Anggaran yang berada di Kementerian Kesehatan;

3. Anggaran yang berada di berbagai Kementerian dan Badan di luar Kemenkes; dan

4. Anggaran pemerintah Kabupatan/Kota dan Provinsi.

Penggunaan anggaran BPJS tergantung pada kapitasi dan klaim yang tidak memperhitungkan alokasi perencanaan.

Demi kelangsungan pelaksanaan jaminan kesehatan nasional, maka Indonesia telah mengadopsi konsep asuransi kesehatan dengan tujuan untuk mengurangi risiko masyarakat menanggung biaya kesehatan dari pendapatan sendiri out of pocket, dalam jumlah yang sulit diprediksi dan memerlukan biaya yang sangat besar. Untuk itu diperlukan suatu jaminan dalam bentuk asuransi kesehatan dimana peserta membayar premi dengan besaran tetap. Dengan demikian pembiayaan kesehatan ditanggung bersama secara gotong royong oleh keseluruhan peserta, sehingga tidak memberatkan secara orang per orang, maka terbentuklah Badan Penyelenggara Jaminan

\footnotetext{
18 Lihat Pasal 7 PP Nomor 38 Tahun 2007 tentang Pembagian Urusan Pemerintahan antara Pemerintah, Pemerintah Daerah Provinsi dan Pemerintah Daerah Kabupaten/Kota.
}

Sosial (BPJS) ${ }^{19}$. Pada tanggal 3 November 2014, Presiden Joko Widodo mengeluarkan program kesehatan lain yang bernama Kartu Indonesia Sehat yang selanjutnya disingkat dengan KIS. KIS merupakan kartu yang memiliki fungsi untuk memberikan jaminan kesehatan kepada masyarakat untuk mendapatkan pelayanan kesehatan secara gratis. Untuk penggunaannya dapat menggunakan fungsi KIS di setiap fasilitas kesehatan tingkat pertama dan tingkat lanjut. Tapi, ternyata KIS dan BPJS memiliki perbedaan, antara lain:

1. KIS merupakan jaminan kesehatan yang diperuntukkan bagi masyarakat yang tidak mampu, sedangkan BPJS yaitu sebuah badan atau lembaga yang menyelenggarakan dan mengelola jaminan kesehatan tersebut;

2. KIS hanya diperuntukkan bagi seseorang yang di mana kondisi ekonominya sangat lemah, sedangkan BPJS merupakan jaminan kesehatan yang diwajibkan bagi setiap Warga Negara Indonesia baik yang mampu ataupun tidak mampu. Bagi rakyat yang tidak mampu, iurannya ditanggung oleh pemerintah;

3. Pemakaian KIS dapat dilakukan di mana saja, baik di klinik, puskesmas atau di rumah sakit manapun yang ada di Indonesia. Sedangkan, pemakaian BPJS hanya berlaku di klinik atau puskesmas yang telah didaftarkan saja;

4. KIS dapat digunakan tidak hanya untuk pengobatan saja, tetapi juga dapat digunakan untuk melakukan pencegahan. Sedangkan, penggunaan BPJS hanya dapat digunakan jika kondisi kesehatan peserta sudah benar-benar sakit atau harus dirawat;

5. KIS merupakan jenis jaminan kesehatan yang mendapatkan subsidi dari pemerintah, sedangkan pengguna BPJS diwajibkan untuk membayar iuran setiap bulannya dengan jumlah yang telah ditentukan.

KIS merupakan perluasan dari JKN yang dijalankan oleh BPJS Kesehatan. KIS ini ditujukan bagi masyarakat yang tidak mampu yang seharusnya masuk peserta Penerima

\footnotetext{
${ }^{19}$ Kementerian Kesehatan RI, Buku Pegangan Sosialisasi: Jaminan Kesehatan Nasional (JKN) dalam Sisem Jaminan Sosial Nasional, hlm. 13.
} 
Bantuan luran (PBI) dalam BPJS Kesehatan, namun bagi yang belum terjangkau. Selain itu, KIS memberikan tambahan manfaat dalam pelayanan, antara lain layanan preventif, promotif dan deteksi dini yang akan dilakukan secara lebih intensif dan terintegrasi ${ }^{20}$.

Jaminan Kesehatan Nasional (JKN) telah meningkatkan akses masyarakat terhadap pelayanan masyarakat dan targetnya adalah semua warga negara tercangkup ke seluruh sistem pelayanan kesehatan (Universal Health Coverage). JKN menerapkan sistem pelayanan kesehatan berjenjang. Dimana sistem tersebut terdiri dari Fasilitas Kesehatan Tingkat Pertama yang selanjutnya disingkat dengan FKTP dan Fasilitas Kesehatan Rujukan Tingkat Lanjutan yang selanjutnya disingkat FKRTL, yang terdiri dari pelayanan kesehatan tingkat kedua (sekunder) dan pelayanan kesehatan tingkat ketiga (tersier) ${ }^{21}$. Pasien yang ingin mendapatkan pelayanan kesehatan harus menyesuaikan dengan sistem berjenjang tersebut. Sistem rujukan dilakukan sebagai bentuk pelimpahan tugas dan tanggung jawab pelayanan kesehatan secara timbal balik, baik secara vertikal maupun horizontal kepada pasien di seluruh fasilitas kesehatan ${ }^{22}$. Daripada itu juga, sistem rujukan berjenjang secara tidak langsung dapat memperbaiki fasilitas kesehatan di semua tingkatan. Tujuannya, yaitu agar pelayanan kesehatan di semua FKTP menjadi lebih baik dan optimal.

Dalam implementasinya ternyata masih banyak masalah yang ditemukan. Dukungan pembiayaan dan kepesertaan masih belum optimal. Tingginya permintaan masyarakat terhadap pelayanan kesehatan tidak didukung oleh sistem pembiayaan yang baik, akibatnya setiap tahun pembiayaan untuk JKN mengalami defisit $^{23}$. Kementerian Keuangan menjelaskan 4

\footnotetext{
${ }^{20}$ Zahry Vandawati, Hilda Yunita Sabrie, Widhayani Dian dan Rizky Amalia, "Aspek Hukum Kartu Indonesia Sehat", Fakultas Hukum Universitas Airlangga, Yuridika Volume 31 No. 3, September 2016.

21 Darmawan, RI, Thabrany.H. "Refleksi Implementasi Jaminan Kesehatan Nasional Pada Pelayanan Dokter Gigi di Fasilitas Kesehatan Tingkat Kota Tangerang Tahun 2017". Jurnal Kebijakan Kesehatan Indonesia, Volume 06, Nomor 4, Desember 2017.

22 BPJS Kesehatan. Panduan Praktis Sistem Rujukan Berjenjang. Jakarta: BPJS Kesehatan.

${ }^{23}$ Marina Ery Setiawati, "Evaluasi Pelaksanaan Sistem Rujukan Berjenjang Dalam Program Jaminan Kesehatan
}

(empat) akar masalah kenapa BPJS Kesehatan mengalami defisit, yaitu:

1. Struktur iuran BPJS masih di bawah perhitungan aktuaria atau underpriced, maksudnya adalah iuran yang terlalu kecil dengan manfaat yang terlalu banyak, maka risikonya terlalu tinggi karena peserta BPJS juga yang banyak.

2. Banyaknya Peserta Bukan Penerima Upah (PBPU) dari sektor mandiri atau informal yang hanya mendaftar pada saat sakit lalu berhenti membayar iuran setelah mendapatkan pelayanan kesehatan atau menunggak.

3. Tingkat keaktifan peserta mandiri atau informal yang cukup rendah atau hanya sekitar $54 \%$. Sementara tingkat utilisasi atau penggunaannya sangat tinggi.

4. Beban BPJS Kesehatan pada penyakit katastropik yang sangat besar. Tercatat beban pembiayaan mencapai lebih dari $20 \%$ dari total biaya manfaat.

5. Dari BPKP (Badan Pengawasan Keuangan dan Pembangunan) menemukan adanya data yang bermasalah, perusahaan yang memanipulasi gaji karyawan, potensi penyalahgunaan regulasi dengan memberikan pelayanan rumah sakit lebih tinggi dari seharusnya ${ }^{24}$.

Pemerintah berupaya untuk mengatasi defisit yang terjadi, salah satunya dengan menaikkan tarif iuran. Seperti yang diketahui pada tahun 2020, pemerintah resmi menaikkan iuran program JKN yang dikelola oleh BPJS Kesehatan hingga $100 \%$ dan telah mulai memberlakukan pada awal tahun ini. Kenaikan ini seiring dengan terbitnya Peraturan Presiden Nomor 75 Tahun 2019 tentang Perubahan atas Perpres Nomor 82 Tahun 2018 tentang Jaminan Kesehatan. Dewan Jaminan Sosial Nasional (DJSN) menyebutkan dampak apa saja yang akan terjadi setelah kenaikan tarif iuran BPJS Kesehatan, antara lain meningkatnya jumlah peserta non-aktif kemudian, akan ada penurunan kelas peserta dan calon peserta

Nasional", Jurnal Kebijakan Kesehatan Indonesia: JKKI, Volume 08 Nomor 01, Maret 2019.

24 Agatha Olivia Victoria. 2019. Sri Mulyani Beberkan Empat Penyebab Defisit BPJS Keuangan. https://www.google.com/amp/s/katadata.co.id/amp/beri ta/2019/08/21/sri-mulyani-beberkan-empat-penyebabdefisit-bpjs-keuangan?espv=1 diakses pada 10 Maret 2020 pukul 03.12 Wita. 
enggan untuk membayar karena kenaikan tarif yang cukup besar. Perlu diketahui per 31 Oktober 2019, peserta BPJS Kesehatan berjumlah 222,27 juta jiwa. Sebanyak 133,8 juta jiwa diantaranya merupakan peserta PBI yang dibiayai oleh pemerintah ${ }^{25}$. Dengan kenaikan tarif iuran ini, maka BPJS Kesehatan dituntut untuk harus memastikan kualitas pelayanan kesehatan lebih baik, penyediaan sarana, peningkatan mutu kesehatan, serta transparansi sehingga tidak ada penggelapan iuran. Sebab dengan kenaikan tarif iuran maka akan ada perbaikan arus kas pada BPJS Kesehatan. Berdasarkan Perpres Nomor 75 Tahun 2019, besaran untuk tarif kenaikan iuran BPJS Kesehatan naik hingga mencapai seratus persen, antara lain Peserta BPJS Kesehatan kelas mandiri I naik dari Rp 80.000,- per bulan menjadi Rp 160.000,- per bulan, untuk kelas mandiri II naik dari Rp 51.000,- per bulan menjadi Rp 110.000,- per bulan, dan untuk kelas mandiri III naik dari Rp 25.500,- per bulan menjadi Rp 42.000,- per bulan. Sedangkan untuk iuran peserta PBI yang dibiayai oleh pemerintah juga ikut naik, dari Rp 23.000,- per bulan menjadi Rp 42.000,- per bulan. Akan tetapi, pada Maret 2020 Mahkamah Agung (MA) mengabulkan uji materi Perpres Nomor 75 Tahun 2019, khususnya aturan kenaikan iuran BPJS yang mencapai seratus persen per 1 Januari 2020. Dalam putusannya, MA membatalkan aturan kenaikan iuran BPJS seperti yang tercantum dalam Pasal 34 ayat (1), (2) Perpres Nomor 75 Tahun 2019.

\section{PENUTUP}

\section{A. Kesimpulan}

1. Hak atas kesehatan sebagai hak mendasar bagi setiap individu secara tegas telah dinyatakan dalam Pasal $28 \mathrm{H}$ dan Pasal 34 Undang-Undang Dasar 1945 dan Undang-Undang Nomor 11 Tahun 2005 tentang Pengesahan International Covenant on Economic, Social and Cultural Rights bahwa setiap orang berhak atas pelayanan kesehatan dan

\footnotetext{
${ }^{25}$ Fransisca Christy Rosana. 2019. Iuran BPJS Kesehatan Resmi Naik, Ini Dampaknya. https://www.google.com/amp/s/bisnis.tempo.co/amp/12 68895/iuran-bpjs-kesehatan-resmi-naik-inidampaknya?espv=1 diakses pada 08 Maret 2020 pada pukul 02.13 Wita.
}

negara bertanggung jawab atas penyediaan fasilitias pelayanan kesehatan. Berdasarkan hal tersebut, upaya pemenuhan hak atas kesehatan bagi seluruh masyarakat, maka dibentuklah Undang-Undang Nomor 36 Tahun 2009 tentang Kesehatan, UndangUndang Nomor 40 Tahun 2004 tentang Sistem Jaminan Sosial Nasional, UndangUndang Nomor 24 Tahun 2011 tentang Badan Penyelenggara Jaminan Sosial dan Peraturan Presiden Nomor 82 Tahun 2018 tentang Jaminan Kesehatan.

2. Jaminan Kesehatan Nasional menerapkan sistem pelayanan kesehatan berjenjang, yang terdiri atas Fasilitas Kesehatan Tingkat Pertama (FKTP) dan Fasilitas Kesehatan Tingkat Rujukan Lanjutan (FKRTL). Dalam hal pembiayaan kesehatan, sumber pembiayaan berasal dari pemerintah yang diatur dalam Pasal 171 UU Nomor 36 Tahun 2009 tentang Kesehatan, dialokasikan sebesar $5 \%$ dari APBN di luar gaji dan sebesar $10 \%$ dari APBD di luar gaji.

\section{B. Saran}

1. Ketersediaan sarana dan prasarana yang baik dan ketersediaan sumber daya manusia kesehatan seperti dokter yang mempunyai kompetensi yang baik dalam jumlah yang cukup disetiap FKTP adalah 2 hal yang harus menjadi perhatian. Peningkatan mutu pelayanan di FKTP dan FKRTL harus segera di perbaiki, agar masyarakat bisa semakin mudah untuk mendapatkan akses dalam pelayanan kesehatan. Sosialisasi secara intensif harus dilakukan kepada masyarakat agar mereka memahami prosedur sistem rujukan berjenjang yang berlaku dalam Jaminan Kesehatan Nasional.

2. Masalah-masalah yang dihadapi oleh BPJS saat ini seperti defisit, kemudian yang bersifat regulasi, administrasi dan teknis harus segera diatasi dan dijadikan bahan perbaikan agar kedepannya BPJS Kesehatan dapat melayani seluruh masyarakat Indonesia lebih baik lagi. Maka dari itu, pemerintah perlu membuat atau memperbaiki peraturanperaturan yang bersifat kelembagaan, 
administrasi dan teknis. Seperti Pasal 52 huruf (p) Perpres Nomor 82 Tahun 2018 tentang Jaminan Kesehatan harus ditegaskan kembali mengenai maksud dan jenis pelayanan kesehatan pada kejadian tak diharapkan yang dapat dicegah dan lebih mempertegas lagi sanksi administratif dalam Perpres Nomor 86 Tahun 2013, seperti besaran denda yang harus dibayar oleh penunggak. Kemudian, dilakukan monitoring dan evaluasi terhadap pelaksanaan jaminan kesehatan nasional.

\section{DAFTAR PUSTAKA}

Amiruddin dan H. Zainal Asikin. 2014. Pengantar Metode Penelitian Hukum, Jakarta: Rajawali Pers.

BPJS Kesehatan. Panduan Praktis Sistem Rujukan Berjenjang. Jakarta: BPJS Kesehatan.

Kansil, C.S.T. 2002. Pengantar Ilmu Hukum dan Tata Hukum di Indonesia, Jilid I. Jakarta: Balai Pustaka.

Kementerian Kesehatan RI, Buku Pegangan Sosialisasi: Jaminan Kesehatan Nasional (JKN) dalam Sistem Jaminan Sosial Nasional.

Komnas HAM. 2009. Komentar Umum Kovenan Internasional Hak Sipil dan Politik, Hak Ekonomi Sosial dan Budaya (Komentar Umum 14 tentang Hak atas Standar Kesehatan Tertinggi yang Dapat Dijangkau). Jakarta: Komisi Nasional Hak Asasi Manusia.

Safroni Ladzi. 2012. Manajemen dan Reformasi Pelayanan Publik dalam Konteks Birokrasi Indonesia. Surabaya: Aditya Media Publishing.

Tjandra, W. Riawan. 2008. Hukum Administrasi Negara. Yogyakarta: Universitas Atma Jaya.

\section{JURNAL:}

Ali, F. A., Kandou, G. \& Umboh, J. 2015. Analisis Pelaksanaan Rujukan Rawat Jalan Tingkat Pertama Peserta Program Jaminan Kesehatan Nasional (JKN) di Puskesmas Siko dan Puskesmas Kalumata Kota Ternate Tahun 2014. JIKMU, 5(2).
Daftar WHO Mengenai Obat-Obatan Essensial. 1999. Direvisi Desember 1999, Informasi Obat WHO, vol. 13, No.4.

Darmawan, RI, Thabrany.H. 2017. Refleksi Implementasi Jaminan Kesehatan Nasional Pada Pelayanan Dokter Gigi di Fasilitas Kesehatan Tingkat Kota Tangerang Tahun 2017. Jurnal Kebijakan Kesehatan Indonesia, Volume 06, Nomor 4.

Firdaus Insan. 2014. Pemenuhan Hak Atas Kesehatan melalui Badan Penyelenggara Jaminan Sosial Kesehatan di Indonesia. Jurnal Hak Asasi Manusia Volume 5 No. 2.

Goniwala, G. 2017. Gambaran Pelaksanaan Rujukan Peserta BPJS Kesehatan di Puskesmas Tikala Baru dan Puskesmas Teling Atas di Kota Manado. [Online] Available at: http://medkesfkm.unsrat.ac.id/wpcontent/uploads/2017/01/Geby-Goniwala1.pdf.

Mardiansyah Rico. 2018. Dinamika Politik Hukum Dalam Pemenuhan Hak Atas Kesehatan di Indonesia. VeJ Volume 4, Nomor 1.

Ratnasari Dwi. 2017. Analisis Pelakasanaan Sistem Rujukan Berjenjang Bagi Peserta JKN di Puskesmas $X$ Kota Surabaya. JAKI Volume 5 Nomor 2, Juli-September 2017.

Setiawati Ery Marina dan Rahmah Hida Nurrizka. 2019. Evaluasi Pelaksanaan Sistem Rujukan Berjenjang Dalam Program Jaminan Kesehatan Nasional. Jurnal Kebijakan Kesehatan Indonesia: JKKI, Volume 08 Nomor 01.

Setyawan Endra Budi Febri. 2018. Sistem Pembiayaan Kesehatan. Vol. 2 No.4, Malang.

Sulastomo. 2006. Substansi dan Filosofi UU Nomor 40 Tahun 2004 tentang Sistem Jaminan Sosial Nasional. Rakernas SJSN dan Jaminan Sosial Kesehatan, Menkokesra.

Yandrizal, Hendarini, Desri Suryani. 2014. Analisis Ketersediaan Fasilitas dan Pembiayaan Kesehatan pada Pelaksanaan Jaminan Kesehatan Nasional di Provinsi Bengkulu. Jurnal Kebijakan Kesehatan Indonesia, Volume 03, Nomor 04.

Yuniza Eka Mailinda. 2013. Pengaturan Pelayanan Kesehatan Di Kota Yogyakarta 
Setelah Penerapan Otonomi Luas. Mimbar Hukum Volume 25, Nomor 3.

Yustina Wahyati Endang. Hak Atas Kesehatan dalam Program Jaminan Kesehatan Nasional dan Corporate Social Responsibility (CSR). Kisi Hukum Jurnal IImiah Hukum.

Vandawati Zahry, Hilda Yunita Sabrie, Widhayani Dian dan Rizky Amalia. 2016. Aspek Hukum Kartu Indonesia Sehat. Fakultas Hukum Universitas Airlangga, Yuridika Volume 31 No. 3.

Widyasworo Radhitya. 2014. Analisis Pengaruh Pendidikan, Kesehatan, Dan Angkatan Kerja Wanita Terhadap Kemiskinan di Kabupaten Gresik (Studi Kasus Tahun 2008-2012). Jurnal Ilmiah, Fakultas Ekonomi dan Bisnis Universitas Brawijaya, Malang. 